\title{
Bacterial, fungal and yeast contamination in six brands of irreversible hydrocolloid impression materials
}

\author{
Contaminação por bactérias, fungos e \\ leveduras em seis marcas comerciais de \\ materiais de moldagem à base de \\ hidrocolóide irreversível
}

\begin{abstract}
Luciana Assirati Casemiro(a) Carlos Henrique Gomes Martins (b) Fernanda de Carvalho Panzeri Pires de Souza ${ }^{(c)}$

Heitor Panzeri(c)

Isabel Yoko Ito(d)
\end{abstract}

(a) PhD, Professor, School of Dentistry of Franca; (b)PhD, Professor, Laboratory of Microbiology - University of Franca.

(c) PhDs, Professors; (d) Full Professor - School of Dentistry of Ribeirão Preto, University of São Paulo.

\section{Corresponding author:}

Luciana Assirati Casemiro

Avenida Caramuru, 2100 ap. 901

Ribeirão Preto - SP - Brazil

CEP: 14030-000

E-mail: lucianacasemiro@hotmail.com

Received for publication on Nov 29, 2005

Sent for alterations on Sep 22, 2006

Accepted for publication on Nov 16, 2006
Abstract: This study assessed the level of contamination of six commercially available irreversible hydrocolloids (two containing chlorhexidine) and identified the contamination present in the materials. Petri dishes containing selective and enriched culture media were inoculated with alginate powder $(0.06 \mathrm{~g})$, in triplicate. After incubation $\left(37^{\circ} \mathrm{C} / 7 \mathrm{days}\right)$, the colony-forming units (CFU) were counted and Gram stained. Biochemical identification of the different morphotypes was also performed. The contamination levels for the materials were: Jeltrate - 389 CFU/g; Jeltrate Plus - 516 CFU/g; Jeltrate Chromatic - 135 CFU/ g; Hydrogum - 1,455 CFU/g; Kromopan - 840 CFU/g; and Greengel - 59 CFU/g. Gram staining revealed the presence of Gram-positive bacillus and Gram-positive cocci. The bacteria Staphylococcus epidermidis, Bacillus subtilis, Bacillus sp., Bacillus coagulans, Bacillus licheniformis, Bacillus cereus, Micrococcus luteus, and Nocardia sp.; the filamentous fungi Aspergillus niger, Aspergillus flavus, Rhizopus sp., Neurospora sp.; and the yeast Candida sp. were isolated. The contamination detected in the impression materials points out the need for adopting measures to improve the microbiological quality of these materials. The use of contaminated materials in the oral cavity goes against the basic principles for controlling cross-contamination and may represent a risk for debilitated or immunocompromised patients.

Descriptors: Dental materials; Microbiology; Infection control.

Resumo: Este estudo avaliou o nível de contaminação de seis marcas comerciais de alginato (duas contendo clorexidina) e identificou a contaminação presente nesses materiais. Alíquotas de alginato $(0,06 \mathrm{~g})$ foram semeadas em meios de cultura seletivos e enriquecidos, em triplicata. Após incubação $\left(37^{\circ} \mathrm{C} / 7\right.$ dias $)$, as unidades formadoras de colônia (UFC) foram contadas e foram realizadas as identificações morfotintorial (Gram) e bioquímica. Os níveis de contaminação dos materiais foram: Jeltrate - 389 UFC/g; Jeltrate Plus - 516 UFC/g; Jeltrate Chromatic - 135 UFC/g; Hydrogum - 1.455 UFC/g; Kromopan - 840 UFC/g; e Greengel - 59 UFC/g. A coloração de Gram revelou a presença de bacilos Gram-positivos e cocos Gram-positivos. As bactérias Staphylococcus epidermidis, Bacillus subtilis, Bacillus sp., Bacillus coagulans, Bacillus licheniformis, Bacillus cereus, Micrococcus luteus e Nocardia sp.; os fungos filamentosos Aspergillus niger, Aspergillus flavus, Rhizopus sp., Neurospora sp.; e a levedura Candida sp. foram isolados. A contaminação detectada nos materiais aponta a necessidade de adoção de medidas para melhorar seu controle de qualidade microbiológica. O uso de materiais contaminados na boca contradiz os princípios básicos de controle de infecção-cruzada e pode representar um risco para pacientes debilitados ou imunocomprometidos.

Descritores: Materiais dentários; Microbiologia; Controle de infecções. 


\section{Introduction}

For years, researchers and manufacturers have put much effort in developing and enhancing dental materials in the search for excellence in their physical, mechanical, and biological properties. Nonetheless, certain materials, such as irreversible hydrocolloids, still show deficiencies, and it is possible to isolate and identify viable microorganisms and fungi in the powder of commercialized containers. ${ }^{16-19}$

Rice et al. ${ }^{19}$ (1990) found viable Gram-negative cocci and Gram-negative rods in $25 \%$ of the assessed alginate samples. According to those authors, the scarcity of data concerning alginate contamination in the literature may be the reason for the little questioning about the possibility of contaminating immunocompromised patients with these materials. After that, other studies were performed, ${ }^{16-18}$ pointing out the contamination of various brands, including those containing antimicrobial agents. ${ }^{16}$

As to the addition of antimicrobial agents to dental materials, ${ }^{7}$ this has been a current tendency, with the goal of inhibiting or avoiding the adhesion and growth of microorganisms. In irreversible hydrocolloids, ${ }^{11}$ besides promoting disinfection of the impressions, the added antimicrobial agents may act as preservatives, reducing the presence of viable microorganisms in the powder. These materials show a better microbiologic quality when compared to alginates without antimicrobial agents; however, adding antimicrobial agents to these materials does not mean they will be free from microorganisms. ${ }^{16} \mathrm{Be}-$ cause alginates have polysaccharide structures similar to those of agar (excellent substrate for microorganisms), it seems unlikely that alginate powders would be free from microorganisms.

The possibility of contaminating immunocompromised patients in dental procedures of minor complexity, since they are susceptible to infections by microorganisms of low virulence, has been pointed out. ${ }^{12}$ Given that it is impossible to determine the patients' immunological condition during each dental treatment, there is a need for adopting the concept of universal precaution. ${ }^{2}$

Impression procedures frequently cause bleeding of the mouth's soft tissues. Considering that blood is a rich culture and microbial transportation medium, and that any rupture of skin integrity offers an opening for the entrance of potentially pathogenic microorganisms, ${ }^{5}$ there is a risk of accidental transmission of this infectious substrate to undesired places. Hence, the use of contaminated impression materials may represent an additional risk of inoculation of microorganisms and, consequently, of occurrence of diseases in immunocompromised patients.

It has long been known that irreversible hydrocolloids may contain viable microorganisms; ${ }^{16-19}$ however, it seems that, until today, no measures have been taken by manufacturers to avoid such contamination. Due to the risk posed by contaminated irreversible hydrocolloids, there is a need for improvement from a microbiological point of view. Sterilization methods should be incorporated, such as irradiation with gamma rays at the end of production. Nonetheless, such method requires a previous knowledge concerning microbial load, both qualitatively and quantitatively, in order to determine the doses to be applied. This fact was the motivation for the present study.

This study's goal was to assess the level of contamination of six irreversible hydrocolloids (two containing antimicrobial agents), and isolate and identify the contamination present in these materials.

\section{Material and Methods}

Sealed containers of the materials (Table 1 ) were opened aseptically, in a laminar flow hood (VECO, Campinas, SP, Brazil), and $0.06 \mathrm{~g}$ samples were removed, one from each package. The powder was inoculated, in triplicate, onto the culture media (Difco Laboratories, Detroit, NJ, USA) Blood Agar (for Gram-positive and Gram-negative bacteria), Mueller-Hinton Agar (for Gram-positive and Gram-negative bacteria), McConkey Agar (for Gram-negatives), Eosin Methylene Blue Agar (for Gram-negative rods), Mitis Salivarius Agar (for Streptococcus), and Sabouraud Dextrose Agar (for fungi and yeasts). After incubation in aerobiosis $\left(7 \mathrm{days} / 37^{\circ} \mathrm{C}\right)$, the colony-forming units (CFU) were counted based on the values obtained for $0.06 \mathrm{~g}$, and means and standard deviations were calculated. The results were analyzed by ANOVA and Tukey's test to determine significant differences between the groups $(\mathrm{p}<0.05)$. 
Table 1 - Irreversible hydrocolloids, their manufacturers, compositions, and batches.

\begin{tabular}{l|l|l|l}
\hline Trade Name & \multicolumn{1}{|c|}{ Manufacturer } & \multicolumn{1}{|c}{ Composition } & \multicolumn{1}{|c}{ Batch number } \\
\hline Jeltrate & $\begin{array}{l}\text { Dentsply Indústria e Comércio Ltda., } \\
\text { Rio de Janeiro, RJ, Brazil }\end{array}$ & $\begin{array}{l}\text { Diatomite, potassium alginate, calcium sulfate, magnesium oxide, } \\
\text { tetrasodium pyrophosphate and spearmint oil }\end{array}$ & 63005 \\
\hline Jeltrate Plus & $\begin{array}{l}\text { Dentsply Indústria e Comércio Ltda., } \\
\text { Rio de Janeiro, RJ, Brazil }\end{array}$ & $\begin{array}{l}\text { Diatomite, potassium alginate, sodium alginate, calcium sulfate, } \\
\text { tetrasodium pyrophosphate, magnesium oxide, potassium } \\
\text { fluortitanate, propyleneglycol, flavors, colorings }\end{array}$ & 54944 \\
\hline Kromopan & Lascod S.p.A., Firenze, Tuscany, Italy & Sodium alginate, calcium sulfate, diatomite powder, coloring agent & 014929169051 \\
\hline Hydrogum & $\begin{array}{l}\text { Zhermack S.p.A., Badia Polesine, } \\
\text { Rovigo, Italy }\end{array}$ & $\begin{array}{l}\text { Sodium alginate, calcium sulfate, potassium fluortitanate and } \\
\text { colorings }\end{array}$ & A0187 B \\
\hline $\begin{array}{l}\text { Jeltrate } \\
\text { Chromatic }\end{array}$ & $\begin{array}{l}\text { Dentsply Indústria e Comércio Ltda., } \\
\text { Rio de Janeiro, RJ, Brazil }\end{array}$ & $\begin{array}{l}\text { Diatomite, potassium alginate, calcium sulfate, sodium phosphate, } \\
\text { magnesium carbonate, chlorhexidine, flavours and colorings }\end{array}$ & 142922 \\
\hline Greengel & $\begin{array}{l}\text { Dentsply Indústria e Comércio Ltda., } \\
\text { Rio de Janeiro, RJ, Brazil }\end{array}$ & $\begin{array}{l}\text { Diatomite, potassium alginate, calcium sulfate, tetrasodium } \\
\text { pyrophosphate, chlorhexidine, flavours and colorings }\end{array}$ & 65056 \\
\hline
\end{tabular}

The morphology of the colonies was observed in a stereoscopic microscope (SMZ645, Nikon, Tokyo, Japan), under reflected light. The biochemical identification ${ }^{14}$ of the different morphotypes was performed in the following manner.

- Bacteria Identification: Fermentation of glucose, lactose, sucrose, maltose, mannitol and sorbitol. Use of citrate and malonate as the only carbon source. Hydrolyses of urea, gelatin, starch, and lecithin. Decarboxylation of lysine, ornithine and arginine. Production of nitrite, acetoin, $\mathrm{H}_{2} \mathrm{~S}$, indole, and phenylpyruvic acid.

- Fungi Identification: The identification of fungi was based on their macroscopic colonial morphology ${ }^{8,10}$ and on their microscopic aspect, using the microculture technique. ${ }^{10}$

\section{Results}

Table 2 shows the levels of contamination detected in the powders and the isolated contaminants. The samples inoculated in Blood Agar, MuellerHinton Agar, and Sabouraud Dextrose Agar presented microbial and fungal growth.

\section{Discussion}

The overall level of contamination was high for the materials studied, ranging from 1,455 CFU/g to $59 \mathrm{CFU} / \mathrm{g}$; these means were significantly different $(\mathrm{p}<0.05)$. In a previous study, ${ }^{16}$ the alginates without antimicrobial agents showed a contamination of 9-161.1 CFU/g, which was smaller than that ob- served for most of the alginates assessed in this study. However, alginates containing antimicrobial agents showed a better microbiologic quality, $135 \mathrm{CFU} /$ g (Jeltrate Chromatic) and $59 \mathrm{CFU} / \mathrm{g}$ (Greengel). Comparing this best result with those obtained in another study ${ }^{16}$ for alginates with chlorhexidine (2.8 CFU/g) and cetylpyridinium chloride (2.8 CFU/ g), it was observed that the latter were smaller than those observed in the present study. The best results obtained in this study may be due to the presence of chlorhexidine diacetate $0.05 \%$, which may have acted as a preservative. The quality of the raw material and the manufacturing, packaging and storing procedures may also have influenced this result. ${ }^{3}$

The materials containing chlorhexidine - Greengel and Jeltrate Chromatic - presented the lowest contamination levels, respectively $59 \mathrm{CFU} / \mathrm{g}$ and $135 \mathrm{CFU} / \mathrm{g}$. Chlorhexidine is a cationic agent with a broad-spectrum antibacterial and antifungal activity. It is also biocompatible with mouth tissues. It has substantivity, which is the ability to remain on a particular surface and be gradually released. ${ }^{15}$ Its excellent properties have motivated its increasing use in dentistry.

Besides chlorhexidine, other components in the formulation of alginates may have influenced the results. Fluoride, for instance, is acknowledged as being antimicrobial. ${ }^{1}$ Its action mechanisms against microorganisms include inhibiting sugar transportation to the interior of the bacteria, and affecting the energetic mechanisms, the glycolytic pathway, and 
Table 2 - Microorganisms isolated in the impression materials.

\begin{tabular}{|c|c|c|c|}
\hline \multirow{2}{*}{$\begin{array}{l}\text { Brand, media contamination level } \\
\text { (standard deviation), and percentage } \\
\text { of samples contaminated }\end{array}$} & \multicolumn{3}{|c|}{ Isolated contaminants } \\
\hline & Bacteria & Filamentous Fungi & Yeasts \\
\hline $\begin{array}{l}\text { Jeltrate } \\
389( \pm 0.14) \mathrm{CFU} / \mathrm{g} \\
33 \%\end{array}$ & $\begin{array}{l}\text { Staphylococcus epidermidis }(G+C) \\
\text { Bacillus subtilis }(G+B) \\
\text { Bacillus coagulans }(G+B) \\
\text { Bacillus cereus }(G+B) \\
\text { Nocardia sp. }(G+B)\end{array}$ & $\begin{array}{l}\text { Aspergillus niger } \\
\text { Aspergillus flavus } \\
\text { Rhizopus }\end{array}$ & - \\
\hline $\begin{array}{l}\text { Jeltrate Plus } \\
516( \pm 0.41) \mathrm{CFU} / \mathrm{g} \\
38 \%\end{array}$ & $\begin{array}{l}\text { Staphylococcus epidermidis }(G+C) \\
\text { Bacillus coagulans }(G+B) \\
\text { Bacillus cereus }(G+B)\end{array}$ & $\begin{array}{l}\text { Aspergillus flavus } \\
\text { Rhizopus }\end{array}$ & Candida albicans \\
\hline $\begin{array}{l}\text { Kromopan } \\
840( \pm 0.78) \mathrm{CFU} / \mathrm{g} \\
44 \%\end{array}$ & $\begin{array}{l}\text { Staphylococcus epidermidis }(G+C) \\
\text { Bacillus sp. }(G+C) \\
\text { Bacillus coagulans }(G+B) \\
\text { Bacillus cereus }(G+B) \\
\text { Micrococcus luteus }(G+C)\end{array}$ & $\begin{array}{l}\text { Aspergillus niger } \\
\text { Aspergillus flavus } \\
\text { Rhizopus }\end{array}$ & - \\
\hline $\begin{array}{l}\text { Hydrogum } \\
1,455 \text { ( } \pm 0.63) \mathrm{CFU} / \mathrm{g} \\
50 \%\end{array}$ & $\begin{array}{l}\text { Staphylococcus epidermidis }(G+C) \\
\text { Bacillus coagulans }(G+B) \\
\text { Bacillus sp. }(G+B) \\
\text { Bacillus licheniformis }(G+B) \\
\text { Bacillus subtilis }(G+B)\end{array}$ & $\begin{array}{l}\text { Aspergillus niger } \\
\text { Aspergillus flavus } \\
\text { Rhizopus } \\
\text { Neurospora }\end{array}$ & Candida albicans \\
\hline $\begin{array}{l}\text { Jeltrate Chromatic } \\
135( \pm 0.34) \mathrm{CFU} / \mathrm{g} \\
27 \%\end{array}$ & $\begin{array}{l}\text { Staphylococcus epidermidis }(G+C) \\
\text { Bacillus coagulans }(G+B) \\
\text { Bacillus cereus }(G+B)\end{array}$ & - & Candida albicans \\
\hline $\begin{array}{l}\text { Greengel } \\
59( \pm 0.42) \mathrm{CFU} / \mathrm{g} \\
22 \%\end{array}$ & $\begin{array}{l}\text { Staphylococcus epidermidis }(G+C) \\
\text { Bacillus cereus }(G+B)\end{array}$ & - & Candida albicans \\
\hline
\end{tabular}

Abbreviations: G+C - Gram-positive cocci; G+B - Gram-positive bacilli.

the synthesis of glycogen and metalloenzymes. ${ }^{6}$ Two of the materials evaluated - Greengel and Jeltrate Chromatic - contain chlorhexidine in their compositions, but only the former contains Fluoride, which may explain the different levels of contamination $(59 \pm 0.42$ for Greengel and $135 \pm 0.34$ for Jeltrate Chromatic).

Another component with antimicrobial activity is magnesium oxide. ${ }^{20,21}$ When its powder becomes in contact with vegetative cells of Escherichia coli, Bacillus cereus, or Bacillus globigii, it kills over $90 \%$ of them in a few minutes. ${ }^{9}$ It is also active against fungi and yeasts, such as Candida albicans NBRC1060, Saccharomyces cerevisiae NBRC1950, Aspergillus niger NBRC4067, and Rhizopus stolonifer NBRC4781. ${ }^{21}$ Essential oils such as spearmint oil also have antibacterial and antifungal activities. ${ }^{13,22}$ These components may also have helped to reduce the contamination levels presented by the evaluated impression materials; however, lower contamination levels were observed for the irreversible hydrocolloids containing chlorhexidine and Fluoride.

The inoculated samples showed variable contamination levels with microorganisms and fungi. For Jeltrate (33\%), Jetrate Plus (38\%), Kromopan (44\%), Hydrogum (50\%), and Jeltrate Chromatic (27\%), the percentages were above the $25 \%$ found by Rice et al. ${ }^{17}$ (1991). The Greengel product, however, showed a lower percentage of contamination $(22 \%)$.

In the results, the contamination levels were expressed in CFU/g, but it is important to consider that the mean quantity of material used to make an impression is about $20 \mathrm{~g}$, which results in an inoculation of a high number of CFUs for each impression.

Regarding the morphotypes, Gram-positive bacilli and Gram-positive cocci were isolated. However, other researchers ${ }^{19}$ have observed the presence of Gram-negative cocci and Gram-positive rods in materials without antimicrobial agents. 
The microorganisms isolated in all alginates were similar to those detected previously, ${ }^{16-19}$ mostly commensal ones in healthy human beings, and incapable of causing any diseases in a situation of equilibrium. Micrococcus luteus, for example, is not considered a pathogenic, or "disease-causing", organism in healthy people. However, when the patient's immunological conditions are deficient, commensal as well as pathogenic microorganisms may be involved in developing diseases, which is a result of the complex interactions between the infecting organism and the host. ${ }^{2,14}$

Regarding the origin of the contamination present, it may be due to the materials used, to the manufacturing process (contaminated equipment, operators, air and packages), to the casing, transportation, and even caused by the user. ${ }^{3}$ As to the latter, even if the alginates were free of contamination at first, there would certainly still be a possibility of contamination because the material is kept in a large package, whose content is sufficient to perform many impressions. By opening the container,

\section{References}

1. Bowden GH. Effects of fluoride on the microbial ecology of dental plaque. J Dent Res. 1990;69 Spec No:653-9.

2. Cottone JA. Practical Infection Control in Dentistry. Philadelphia: Lea \& Febiger; 1991.

3. Fassihi RA. Preservation of medicines against microbial contamination. In: Block SS. Disinfection, sterilization and preservation. $4^{\text {th }}$ ed. Malvern: Lea $\&$ Febiger; 1991. p. 871-86.

4. Good manufacturing practices, including quality assurance for dental materials. Report to General Assembly, Federation Dentaire Internationale. Int Dent J. 1990;40(4):253-6.

5. Gurevich I. Infection control: Applying theory to clinical practice. In: Block SS. Disinfection, sterilization and preservation. $4^{\text {th }}$ ed. Malvern: Lea \& Febiger; 1991. p. 655-62.

6. Hamilton IR. Biochemical effects of fluoride on oral bacteria. J Dent Res. 1990;69 Spec No:660-7.

7. Imazato S, Torii M, Tsuchitani Y, McCabe JF, Russell RR. Incorporation of bacterial inhibitor into resin composite. $\mathrm{J}$ Dent Res. 1994;73(8):1437-43.

8. Kern ME, Blevins KS. Medical Mycology: A Self-Instructional Text. $2^{\text {nd }}$ ed. Philadelphia: FA Davis; 1997.

9. Koper OB, Klabunde JS, Marchin GL, Klabunde KJ, Stoimenov P, Bohra L. Nanoscale powders and formulations with biocidal activity toward spores and vegetative cells of bacillus species, viruses, and toxins. Curr Microbiol. 2002;44(1):49-55. microorganisms from the environment could be introduced into it, which would make the material inadequate for further use, from a microbiological point of view.

It would therefore be ideal to improve the microbiological quality of commercially available alginates, taking into consideration the Good Manufacturing Codes of Practices, ${ }^{4,23}$ and to determine, by performing other studies, if these materials should be sterile or should be allowed a microbiological limit, both qualitatively and quantitatively. It is also recommended that the packages be presented with a singleuse size (for a single impression) in order to preserve the microbiological quality of the material..$^{24}$

\section{Conclusion}

All the irreversible hydrocolloids studied here presented viable bacteria, fungi, and yeasts. However, the materials containing chlorhexidine showed the lowest contamination levels (Greengel, 59 CFU/ $\mathrm{g}$, and Jeltrate Chromatic, $135 \mathrm{CFU} / \mathrm{g}$ ).

10. Lacaz CS, Porto E, Martins JEC. Micologia Médica. $7^{\text {th }}$ ed. São Paulo: Sarvier; 1984.

11. Lott G, Gribi HK. Aseptic dental alginate impressions. Quintessence Int. 1988;19(8):571-4.

12. McGhee JR, Michalek SM, Cassel GH. Dental Microbiology. New York: Harper Row; 1982.

13. Mimica-Dukic N, Bozin B, Sokovic M, Mihajlovic B, Matavulj M. Antimicrobial and antioxidant activities of three Mentha species essential oils. Planta Med. 2003;69(5):413-9.

14. Murray PR. Manual of Clinical Microbiology. $7^{\text {th }}$ ed. Washington: ASM Press; 1999.

15. Ribeiro J, Ericson D. In vitro bacterial effect of chlorhexidine added to glass ionomer cements. Scand J Dent Res. 1991;99(6):533-40.

16. Rice CD, Dykstra MA, Feil PH. Microbial contamination in two antimicrobial and four control brands of alginate impression material. J Prosthet Dent. 1992;67(4):535-40.

17. Rice CD, Dykstra MA, Gier RE. Bacterial contamination in irreversible hydrocolloid impression material and gingival retraction cord. J Prosthet Dent. 1991;65(4):496-9.

18. Rice CD, Dykstra MA, Gier RE, Cobb CM. Microbial contamination in four brands of irreversible hydrocolloid impression materials. J Prosthet Dent. 1991;65(3):419-23. 
19. Rice CD, Moghadam B, Gier RE, Cobb CM. Aerobic bacterial contamination in dental materials. Oral Surg Oral Med Oral Pathol. 1990;70(4):537-9.

20. Sawai J. Quantitative evaluation of antibacterial activities of metallic oxide powders $(\mathrm{ZnO}, \mathrm{MgO}$ and $\mathrm{CaO})$ by conductimetric assay. J Microbiol Methods. 2003;54(2):177-82.

21. Sawai J, Yoshikawa T. Quantitative evaluation of antifungal activity of metallic oxide powders $(\mathrm{MgO}, \mathrm{CaO}$ and $\mathrm{ZnO})$ by an indirect conductimetric assay. J Appl Microbiol. 2004;96(4):803-9.
22. Soliman KM, Badeaa RI. Effect of oil extracted from some medicinal plants on different mycotoxigenic fungi. Food Chem Toxicol. 2002;40(11):1669-75.

23. Von Bockelmann B. Aseptic Packaging. In: Block SS. Disinfection, sterilization and preservation. $4^{\text {th }}$ ed. Malvern: Lea $\&$ Febiger; 1991. p. 833-45.

24. Warwick EF. Preventing microbial contamination in manufacturing. Cosmetics \& Toiletries. 1993;108(10):77-82. 